\title{
Persona Research for Internet and IPTV in PT. Telkom Indonesia
}

\author{
Muhammad Ricky Febrian, MBA ${ }^{1}$, and Lina Setiawati, MBA ${ }^{2}$ \\ ${ }^{12}$ Business Administration Program, School of Business and Management InstitutTeknologi Bandung \\ (SBM ITB), Bandung, Indonesia
}

\begin{abstract}
In this intense era ofcompetition, dealing with the tight competition in telecommunication industry require a significant strategy in order to get the highest market share in this industry. Many companies become more concernabout with the consumer figures they achieve in the market place. PT Telkom Indonesia, which is the leader in the telecommunication industry in Indonesia, has been preparing a strategy to address theindustry trends and market changes. PT Telkom with 164 products divided into TIMES (Telecommunication, Information, Media, Edutainment and Services) categories has different maturity level of products with diversified business challenges as well. In the early 2015, PT. Telkom launched the triple play services (3P) as their innovative product bundled with fixed line telephone, Internet, and IPTV namely by Indihome.

Regrettably, in the third semesterof 2015 Indihome service penetration targets were not achieved and it was not able to meet the customer needs for data service. Based on Indihome Market Penetration Data, it canbeseen that the achievement of Indihome service was not maximized and many operational divisionfoundithard hard to achieve the target and the churn issue appeareds. Besides, looking from the market share perspective, the market share of PT Telkom in broadband industry was constantly decreasing. It was calculated that PT Telkom has the revenue market share with around 64,23\% which fell by $9 \%$ from the previous years. Because of that PT Telkom should evaluate what factors causing the decreasing market share of Indihome from the customers perspective and what strategies could be implemented by PT. Telkom to face the competition in home service digital product. Analyzing the external factors to identify from industry aspect through the general analysis, industry environment analysis and competitor analysis can solve this issue. Second, the persona research to identify a character of ideal customer for digital home service to know the causing factors from buyer perspectivewasused in order to propose the strategies for Indihome in the future.

The result is, PT. Telkom needs to make aninnovative way to develop their business in home digital service in order to becomes a leading Indonesian digital innovation and globalization. Home Automation, Home Shopping, Mobile remote $T V$, On the go services become a recommendation which are given to PT. Telkom for Indihome.
\end{abstract}

Keywords:Telecommunication industry, Persona research, Consumer behaviour.

\section{Introduction}

\subsection{Background}

Indonesia is one of the developing country which has a sustainable economy growth. Telecommunications sector is one of the contributor of the economic growths in Indonesia. A fairly good growth has been recorded and the product becomes a basic need for society. The development of telecommunications has been proven to provide a huge benefit for all parties. According to the Ministry of Communications and Information Technology quoted by Tempo, it is said that Indonesia is a "The giant digital technology giant who are asleep" while Indonesia's population of 250 million people is a huge market. Digital marketing research agency e-Marketer estimates that by 2018, the number of active users of smartphones in Indonesia will reach more than 100 million people.

There are so many players in telecommunications especially on Internet providers in Indonesia. Starting from the Internet provider only PT. Telkom has broadened its service to the complete package to the digital home service (Telephone, Internet, and cable TV) namely Indihome. It means that the rivalry among the existing competitions in this industry is very high.PT. Telkom is one of the fastest growing telecommunication services providers launched Indihomein 2015 providing a triple play services; fixed line, internet, and internet TV.

Along with Telkom's mission to become the leading Indonesian digital innovation and globalization, PT Telkom feel a little complacency, since the response from reaching customers of Indihome tends to be slow. PT. Telkom launched Indihome with the expectation to meet the customer needs for 3 play services. But regrettably, based on the results of the evaluation in the end of 2015 there were some problems encountered by Ditkons, including failure to achieve the target of 3 million subscribers in 2015 . The decrease in market 
share of Indihome was estimated at $-8.9 \%$ per year (May14 - May 15). On the other hand, market share competitors are expected to continue rising and in 2015 it increased by approximately $6.2 \%$ per year.

Even though PT. Telkom is as the largest market share in broadband industry, the decrease of market share seems very evident. In May 2015, Indihome dominated the market share with only $64.23 \%$, compare to the the previous year which was $73 \%$. The growth level of the market share of major competitor like FirstMedia was increased by to $6.2 \%$ per yearwhileBiznet increased by 1.38 per year. Based on the issues that were outlined above, there is a need of analysing and exploring the factors causing the decreasing market share of Indihome as a product digital home service. In order to propose a recommendation for PT. Telkom for product of digital home service, the following measures are taken

\subsection{Research Question}

Based on the business issue already described, the research questions of this research are:

1. What factors causing the decreasing market share of Indihome from the customer's perspective?

2. What innovation products could be implemented by PT Telkom to face the competition in the digital home service product?

\subsection{Research Objective}

To find the solution of the issue above, several objectives that should be done in this research are as follow:

4. Identifying the causing factors ofdecreasing market share of Indihome from the customer's perspective.

5. Defining productinnovationthat could be implemented by PT. Telkomfromcustomerperspective

\subsection{Research Limitation}

In this research, the business issue profoundly discussed is the analysis of digital home service persona in Indonesia. The study was conducted from April 2016 to August 2016. The object of the research is determined by the preference of the respondents.

\section{Literature Review}

\subsection{External Analysis}

To cope with thefrequent ambiguous and incomplete environmental data and to increase understanding of the general environment, firms engage the external environmental analysis (Ireland, 2011). The external environment analysis consists of General Analysis, Five Porter's Forces (Industry Environment Analysis) and Competitor Analysis.

\subsubsection{General Environment Analysis}

The general environment is composed of dimensions in the broader society that influenced an industry and firms within it. Firms cannot directly control the general environment's segments but firms need to understand all segments and implication selecting and implementing the firm's strategies. The segment that will analysed for research are Political/Legal segment, Economic segment, Sociocultural segment, and Technological segment.

\subsubsection{Industry Environment Analysis (Five Porter's Forces)}

Industry environment has a more direct effect on the firm's strategic competitiveness and ability to earn above- average returns. These factors may be critical determinants of the threats and opportunitiesfromcompany that will face in the future. The key issues are how these general environment factors affect the firm's industry environment.

\subsubsection{Competitor Analysis}

Competitor analysis focuses on each company against which a firm directly competes. Critical to an effective competitor analysis is gathering data and information that can help the firm understand its competitor's intentions and the strategic implications resulting from them. 


\subsection{Root Cause Analysis (Five Whys)}

The root cause analysis is conducted from the identified issues from all the analysis to find which components need to be focused on developing the right business strategies. Using the "five Whys" approach to root cause analysis method helps to determine the cause-effect relationships in a problem or a failure.

\subsection{Persona}

A buyer persona is a brief biography with a picture representing the ideal customer. It's a fictional character created from real information about the buyers, their habits, demographics and motivations. It's something that can look at to help guide your sales and marketing decisions, from the kind of content that will likely interest them, to which social networks they prefer (BNG Design, 2016).A buyer persona is an example of the real person who buys, or might buy, products like the ones you market based on what you learn from direct interview with them (Revella, 2011). Creating buyer personas is the process of conducting one-on-one interviews with customers to get a handle on their mind-sets and understand their purchasing decisions.

By following the five steps for gathering the information to gain buyer personas, like below:

1. Respondent screening: Respondent screening are placed at the beginning of a survey

2. Collecting data: Thenext process is collected data through In-depth interview activities

3. Transcript and affinity mapping: Transcript the data and mapping those result into 5 dimensions

4. Define categories: The results are identifying with each same attribute, grouping those attributes, and validate those categories to all respondent and start to count.

5. Find the pattern: The persona will appear through mapping several dimension spectrums.

\section{Research Approach and Method}

\subsection{Conceptual Framework}

In order to solve the business issue faced by PT. Telkom, author will formulate the conceptual framework through strategic management, as the following activities below:

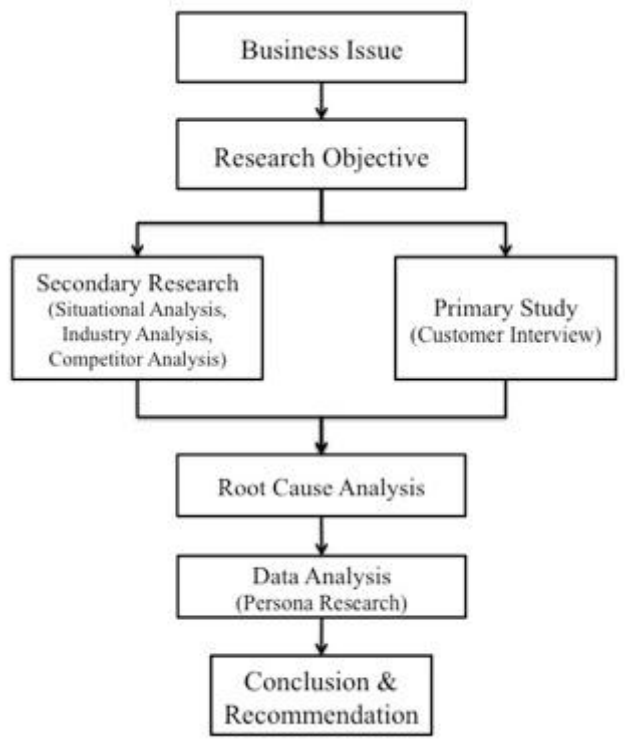

Fig. 1 : Conceptual Framework

Secondary research and primary study were conducted using the framework of external factors and persona research, it was expected that it would generate an alternative business solution that could solve the problems and issues faced by PT Telkom.

\subsection{Data Collection}

Data were gathered primarily through In-Depth interviews. A total of 33 semi-structured interviews were conducted with individuals from require points in respondent screening phase. To determinethe appropriate respondents and interviews were conducted in accordance with the criteria of the screening process, by 
distributing questionnaires offline by visiting houses prospective respondent. By interviewing these individuals, first-hand information couldbeobtainfrom a variety of perspectives through Home-Visit Interview and Home Observation. Those methods are implemented in order to understand the natural context of respondent with a real evidence of the product digital home service which they used.

\subsection{Data Analysis}

The information obtained from the interviews then transcribed to five categories to get the pattern from buyer persona of their mind-sets and behaviour to do purchasing decisions. Based on five dimensions that resulted by consulted with management of PT. Telkom, there were 5 dimension that can be used as categories, which are; Needs, Motivation, Pain, Tools\& Technology, and Buying Behaviour.

Thus, this research analysed the data with identifying five categories of buyer persona, classifying the type of buyer persona, and analyzing how the type of buyer persona will impact the way product digital home service will be chosen and how PT. Telkom can take an advantage of this buyer persona.

\subsubsection{Measurement Scale}

Based on the persona research analysis already mentioned above, to classify five categories will use the measurement which already discussed with the management according to the initial survey before the persona research has been taken.

TABLE I Measurement Scale

\begin{tabular}{|c|c|}
\hline Needs & 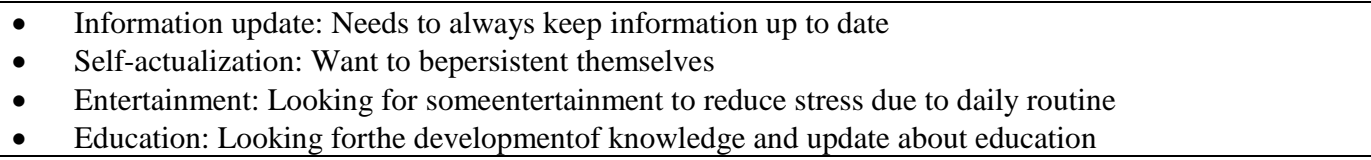 \\
\hline Motivation & $\begin{array}{l}\text { - Increase life value: toImprove the value through education things } \\
\text { - Increase life welfare:to Improve the welfare through increasing the income from internet } \\
\text { - } \quad \text { To enjoy life: toLook for the information about the hobbies and daily activity } \\
\text { - } \quad \text { Daily routine requirement: Doing daily activities is balanced with entertainment and hobbies } \\
\text { - Increase social welfare: toFocus on other people needs (children, family) }\end{array}$ \\
\hline Pain & $\begin{array}{l}\text { - } \quad \text { Access information: The difficulties to seek information that match with needs through digital media } \\
\text { - } \quad \text { Content problem: Bored with the content of thedigital media and feel thatthe contents are inappropriate } \\
\text { - } \quad \text { Inadequate solution: Digital solutions today are not attractive and lacking of desirable features. }\end{array}$ \\
\hline $\begin{array}{l}\text { Tools \& } \\
\text { Technology }\end{array}$ & $\begin{array}{l}\text { - } \quad \text { Basic: Only for personal use in communication (message exchange) } \\
\text { - } \quad \text { Medium: Using ICT as a daily activity platform, especially tobeactive in community } \\
\text { - }\end{array}$ \\
\hline $\begin{array}{l}\text { Buying } \\
\text { Behaviour }\end{array}$ & $\begin{array}{l}\text { - } \quad \text { Online: Prefer buying something through online media } \\
\text { - } \quad \text { Semi: Checking the goods via online, but purchasing through conventional media } \\
\text { - } \quad \text { Offline: Prefer buying something through conventional media }\end{array}$ \\
\hline
\end{tabular}

\section{Result and Analysis}

\subsection{Situational Analysis}

\subsubsection{Political Segment}

The government ofIndonesia nowadays in the periodof presidentcyJokoWidodo and JusufKalla, began applying Digital-based-government concepts, for example, e-government and smart city concepts. Meanwhile, in order to implemented a program of creative industries, the government encourages and supports the program created by HackatonMerdekawhose purpose isto create internet-based products. To increase internet market penetration is one of the government strategies in order to enhance broadband access infrastructure to encourage the telecommunication's players in Indonesia through delivered internet services for residential neighborhood. Indihome, as a forerunner of smart home products, is a solution that can support the success of technology equalization.

\subsubsection{Economic Segment}

In the second quarter of 2015 Indonesia's economy rose to 4.67 percent, and this trend is marked as the lowest since 2009. In the previous, Indonesia's economic growth waspredicted to continue to slow since there had been no solution in theglobal commodity prices, interest rates remained high, the society's purchasing power weakened, thegovernment expenditure remained problematic, companies Q2-2015 earnings reports were rather poor, and manufacturing reduced. It can be concluded that the economic conditions in Indonesia was decreasing but relatively stable. Regarding tothe potential market for IPTV especially market of broadband internet services and pay TV, the market has the potential revenue which is 
quite significant. It can be seen from theincreasingtrend of revenues and the emergence of new players in this market industry. In the case of TV subscription industry, according to PWC, it can be seen that revenue earnings of TV subscription (IPTV, Satellite TV) in Indonesia has a positive trend, where there wasanincrease in revenue from 2008 to 2015 that reached $£ 8.7$ trillion.

\subsubsection{Sociocultural Segment}

The demand for urban lifestyle can be seen from the high mobility and routines to stay connected with each other, anywhere and anytime. Moreover, Internet and television have become the major media to get information for the urban society. The pay TV market (IPTV \& Satellite TV), the trend of pay TV users is predicted annually increase, based on the research by media partner in 2012, as seen from the increasing growth of subscribers IPTV significantly. Besides that, based on Ericsson Consumer Insight Summary Report 2014 that surveyed 23 countries including Indonesia, there are 5 features desired by consumers from TV subscription and video streaming content such as a good video quality (high definition), no ad content, brand new movies, time shift and choice of subtitle language of each country on movie channels.

\subsubsection{Technological Segment}

Technologies play an important role in the development of an industry, especially the telecommunication industry, such as FTTH (Fiber to the Home) tech service is in the form of a combined product, service, broadband Internet, IPTV and fixed line telephone subscription. In order to realize the early stage of the smart home concept. In the future, the concept of smart homes is the provision of not only internet-based content but also application-based technology that can give benefits for the users.

\subsection{Industry Environment Analysis (Five Porter's Force)}

Based on The Porter's Five Forces analysis, this industry can be concluded to be an Attractive industry. Assessed from the threat of substitutes and the rivalry among the competition whichis in High level, the new player that want to enter this market have big barriers as every new provider must provide the physical infrastructure (FTTH) with very high investment needs. But on the other hand, fromthe bargaining powerof supplier's perspective, the supplier in this industry also did not have a strong position because of the purchased material from the company to supplier will make a significant effect into supplier revenue. Furthermore, the competition level of supplierwill automatically high because there are many companies that also provide the similarproducts. The sameas with the bargaining power of the buyer, the buyers also do not have a strong position, although there are many choices that can be choosen by the buyers, the buyer cannot switch their products easily as theythenneed to spend much more money in order to switch the devices.

\subsection{Competitor Analysis}

As a telecommunication company that provides integrated smart home service such as Indihome, PT Telkom does not have head-to-head competitors. Until now there is no telecommunication company that is engaged in offering service like Indihome product. However, there are several companies that offer the same services like Indihome product. In this case, there are a few companies engaged in the field of FTTH service (fixed line, broadband internet, and IPTV) and Indihome competitors are companies which havethe Internet and IPTV providers using FTTH technology. Currently, there are only three competitors, namely First Media, My Republic and MNC Group. In this section a competitor analysis is conducted by collecting data from secondary data (processed data from the internet).

TABLE III Competitor Analysis

\begin{tabular}{|c|c|c|c|c|}
\hline Company & PT. Telkom & PT. Link Net & Sinarmas & MNC Group \\
\hline Product & Indihome & First Media Combo HD & My Republic & MNC Play Media \\
\hline $\begin{array}{l}\text { Current } \\
\text { Business } \\
\text { Strategy }\end{array}$ & Differentiation & $\begin{array}{l}\text { Integrated Cost Leadership \& } \\
\text { Differentiation }\end{array}$ & Cost Leadership & $\begin{array}{l}\text { Integrated Cost } \\
\text { Leadership \& } \\
\text { Differentiation }\end{array}$ \\
\hline $\begin{array}{l}\text { Assumptions } \\
\text { about Industry }\end{array}$ & Attractive & Attractive & Attractive & Attractive \\
\hline $\begin{array}{l}\text { Objectives } \\
\text { (Financial vs. } \\
\text { Market Goals) }\end{array}$ & Market Goals & Market Goals & Market Goals & Market Goals \\
\hline Strengths & $\begin{array}{l}\text { Largest coverage area, } \\
\text { Additional support }\end{array}$ & $\begin{array}{l}\text { Many channels (IPTV) than the } \\
\text { others, Service excellent }\end{array}$ & $\begin{array}{l}\text { Lowest price than others } \\
\text { (cost leadership), }\end{array}$ & $\begin{array}{l}\text { Additional support } \\
\text { product, Give the }\end{array}$ \\
\hline
\end{tabular}




\begin{tabular}{|c|c|c|c|c|}
\hline & $\begin{array}{l}\text { product, Complete } \\
\text { smart home solution } \\
\text { than the others }\end{array}$ & & & $\begin{array}{l}\text { smart home } \\
\text { solution }\end{array}$ \\
\hline Weakness & $\begin{array}{l}\text { Higher price than } \\
\text { competitors }\end{array}$ & $\begin{array}{l}\text { Does not have many coverage } \\
\text { area and another product that } \\
\text { support core business, Higher } \\
\text { price than competitors }\end{array}$ & $\begin{array}{l}\text { Does not have many } \\
\text { coverage areas and another } \\
\text { product that support core } \\
\text { business }\end{array}$ & $\begin{array}{l}\text { Does not have } \\
\text { many coverage } \\
\text { areas, Higher price } \\
\text { than competitors }\end{array}$ \\
\hline
\end{tabular}

It can be concluded that PT Telkom has strength especially in the FTTH coverage area. The biggest scope will be the main factor that determined PT. Telkom as a business sector pioneer of this industry. But on the other hand, the competitors now began to expand their FTTH coverage area to gain a growing market share. In order to acquire the customer, Telkom competitors offer the lower prices in comparison with Telkom's products. It had been proved that this strategy is very effective due to the level of market share PT. Telkom began to decline. This strategy is very effective because of the customers tend to use the cheapest price product due to service offered among these business player is similar (several differentiation). In response this condition, focus to do an innovation is a strategy for PT. Telkom in order to create a differential products than competitors. But this strategy is not very effective, many customer feel that the differentiation that created by PT Telkom is not good enough. Because of that the churn rate of PT Telkom is still relatively high. Therefore, PT. Telkom as a market leader must considers a suitable strategy in order to maintain position as a market leader in this industry with more pay attention to market trends and market demands.

\subsection{Customer Interview}

According to the interview about consumer behavior based on brands Internet and IPTV, five from eight Indihome'scustomer feel satisfied with Indihome service, but two people have a plan to switch toother brand. Lack of connectivity Internet and the unstable were the reason from Indihome's customer. In theotherhand, from six existing firstmedia'scustumerswassatisfied to use this product and will not using another brands. The main reason were the stable connectivity and an excellent service when handling complaint. The customer of My Republic said that the product offered with affordable price with never been impaired. Five from eight consumers MNC Play stated that satisfied with the product but two respondents planed to move out with another brands. MNC Play product has a good quality product and an easy installation service, but they offered high price. Therefore, when compared to competitors' products, consumer majorlysatisfied with the service of IPTV and Internet in Indonesia but in thecaseofIndihome,thesatisfaction levelsisthelowest, so some consumers want to switch to competitors' products. It becomes main reasonofthechurn rate that faced by PT. Telkom.

\subsection{Root Cause Analysis (Five Whys)}

Based on the business issue above and also theexplorationof the external environment analysis, industry environment analysis, and competitor analysis, it is known that the decrease of the market share has become a problem for PT Telekomunikasi Indonesia in order to maintain their position as the market leader. In order to analyzetheroot cause of the problem faced by PT. Telkom, the followingsare the "five whys" analysis that is used to treat the cause of the problems encountered.

TABLE IV Root Cause Analysis

\begin{tabular}{cl}
\hline \hline Problem & $\begin{array}{l}\text { Churn rate of Indihome service began to increase in the third quarter of } 2015 \text { and the level of Telkom's market } \\
\text { share in broadband industry is constantly decreasing. }\end{array}$ \\
\hline Why 1 & $\begin{array}{l}\text { PT Telkom offered Indihome service at ahigher price comparedto other competitors. } \\
\text { PT Telkom wasinvolvetoomany vendors and some of its subsidiaries to support Indihome, both in terms of technical and } \\
\text { product's support, such as customer service and digital product development in order to make a differentiation. On the } \\
\text { other hand the cost of Indihomebecame expensive. }\end{array}$ \\
Why 3 & $\begin{array}{l}\text { PT Telkom tried to make a product/service differentiation through Indihome, but it still did not meet the expectation of } \\
\text { thecustomers, many customersfelt that the Indihome's cost wasnot worth itcompared to the Indihome's benefit }\end{array}$ \\
Why 4 & $\begin{array}{l}\text { Many customer felt that the Indihome's cost was not worthit compared to the Indihome's benefit due to poorservice of } \\
\text { Indihome, } \\
\text { PT Telkom still did not a have suitable strategy in order to fulfill their customer expectation especially in providing the } \\
\text { best product/services and competitive price. }\end{array}$ \\
\hline \hline
\end{tabular}




\subsection{Persona Research}

The company have to know the characteristics oftheconsumers before serving them. Through buyer persona, the company will have a consistent understanding about the target consumers are, so PT. Telkom can target and engage them better, offer relevantinformation, prioritize the solutions and improve the way tomeet their needs.

Subsequently, following five steps from screening, collecting data, mapping categorizing, and finding the pattern from In-Depth interview can process analysis the buyer persona processed through several steps:

- Mapping the result into measurement scale

- Generating the scale into those five categories

- Reviewing the unique categories based on characteristics respondent

- Finding the pattern of persona with the typical name based on characteristics respondent

The categories and the pattern persona of respondent Internet and IPTV are shown in thetable below.

TABLE V Persona Pattern

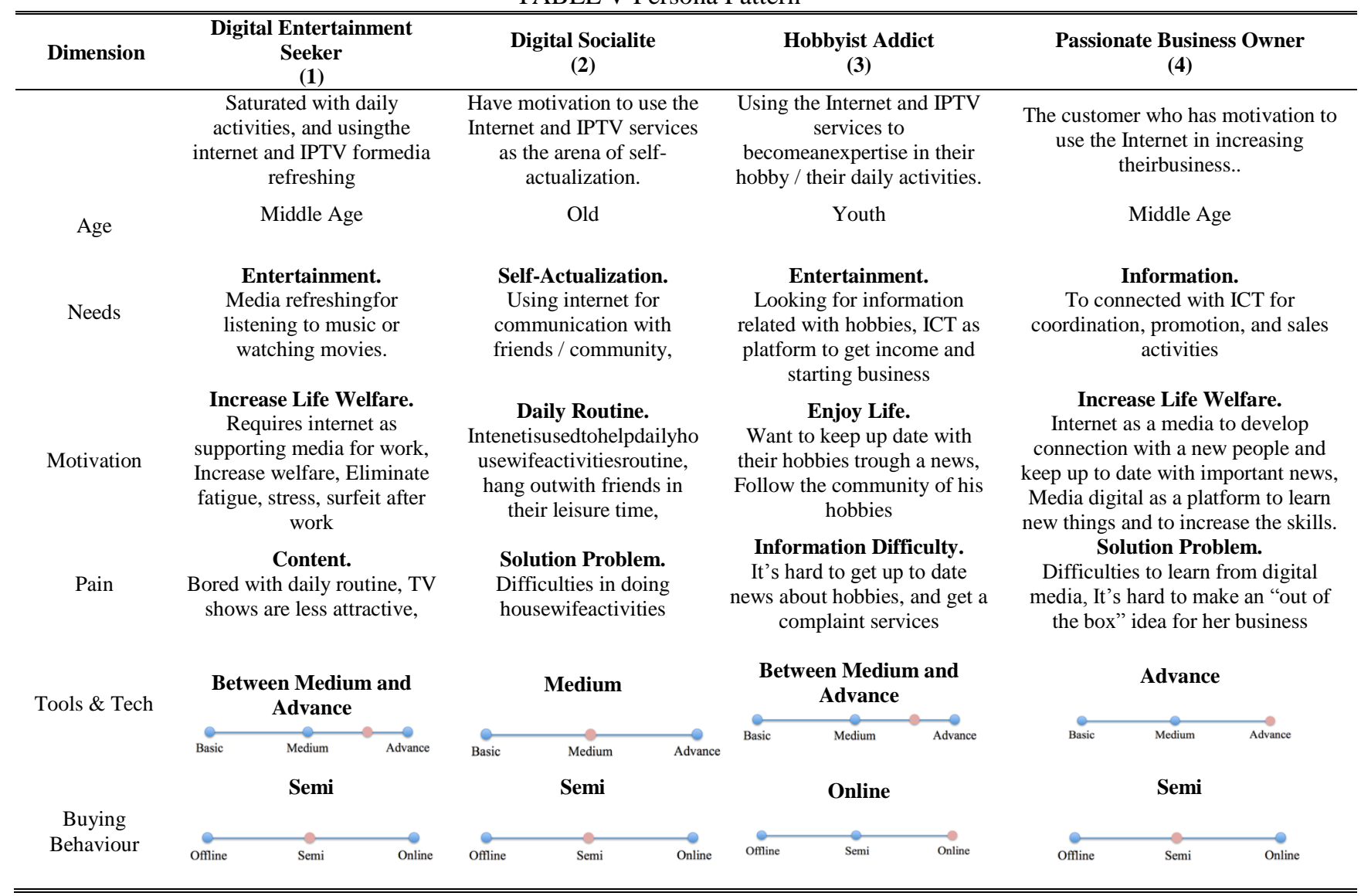

TABLE VI Persona Pattern (cont.)

\begin{tabular}{|c|c|c|c|}
\hline Dimension & $\begin{array}{c}\text { Newbie } \\
\text { Business Startup } \\
(5)\end{array}$ & $\begin{array}{l}\text { Affectionate } \\
\text { Parents } \\
\text { (6) }\end{array}$ & $\begin{array}{l}\text { Enthusiastic } \\
\text { Student } \\
(7)\end{array}$ \\
\hline & $\begin{array}{l}\text { Motivatedtoget a betterincomebymaximizing } \\
\text { internet media, searching for information } \\
\text { aboutdeveloping business }\end{array}$ & $\begin{array}{l}\text { Motivated to help others (familymembers) such } \\
\text { as helping children with homework, looking for } \\
\text { new recipes }\end{array}$ & $\begin{array}{l}\text { Motivated to be able constantly } \\
\text { improve their knowledge, especially } \\
\text { in the academic area. }\end{array}$ \\
\hline $\mathrm{Age}$ & Middle Age & Middle Age & Youth \\
\hline Needs & $\begin{array}{l}\text { Information. } \\
\text { Informationtodeveloptheir business }\end{array}$ & $\begin{array}{l}\text { Education. } \\
\text { Gettinginformationof education for child, } \\
\text { andinformationforhousewiferoutine }\end{array}$ & $\begin{array}{l}\text { Education. } \\
\text { Enrich the knowledge } \\
\text { byonlinelearning }\end{array}$ \\
\hline Motivation & $\begin{array}{l}\text { Increase Life Welfare. } \\
\text { Developing the business, Enrich knowledge } \\
\text { foraccessinformation }\end{array}$ & $\begin{array}{l}\text { Social Welfare. } \\
\text { Keep in touch with their community }\end{array}$ & $\begin{array}{l}\text { Increase Life Value. } \\
\text { Media entertainment to reduce his } \\
\text { stress }\end{array}$ \\
\hline Pain & $\begin{array}{l}\text { Information Difficulty. } \\
\text { Looking for an easier complaint services }\end{array}$ & $\begin{array}{l}\text { Content. } \\
\text { The easywaytosearch for recipe food, visual } \\
\text { information of household products. }\end{array}$ & $\begin{array}{l}\text { Information Difficulty. } \\
\text { It's hardtoenrichtheknowledege }\end{array}$ \\
\hline Tools \& Tech & Advance & Basic & Advance \\
\hline
\end{tabular}



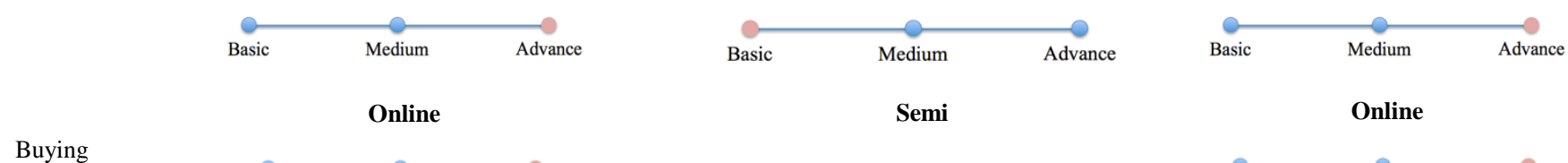

Behaviour

Online
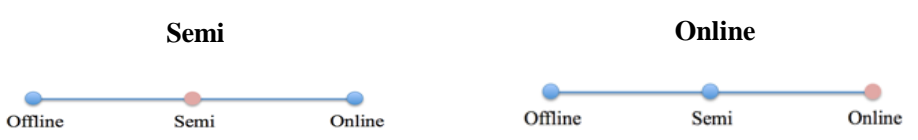

\section{Conclusion and Recommendation}

\subsection{Conclusion}

Based on the data collecting, data processing, and data analyzing have been done in the previous chapter, there are several conclusions thatcanbeseenas follows:

1. The causing factorsofthe decreasing market share of

Indihomeistheindihome'scustomerfeltthattheindohomeservicewas not meettheexpectationofcustomer, manyofthemfeltthatthecompletesolutionofIndihome Services is not $\begin{array}{lll}\text { worthitcomparedtotheirprice. } & \text { PT } & \text { Telkom }\end{array}$ needtobuildaninnovativeproductthroughcustomerneedthatcanbedeliverdbyconsideringthecustomer persona in order toprovidethesuitableinnovationvalueaddedforcustomer's

2. The persona research found seven patterns with different characteristics. The patterns are called Digital entertainment seeker, Digital socialite, Hobbyist addict, Passionate business owners, Newbie startup, Affectionate parents, and Enthusiastic student. Persona research isused for seeking the strategy thatcould be implemented byPT. Telkom for product digital home service. Through these seven patterns, the result of research gives four types ofvalueaddedrecommendation, i.e Home Automation, Home Shopping, Mobile remote TV, On the go services, that could be considered by PT. Telkom in order to solve their problem inthedigital home serviceproduct.

\subsection{Recommendation for PT. Telkom}

Based on research results, the value recommendations been discussed with management and also has been validated to the customer by using questionnaire to the internet and IPTV customers. The recommendations define as follows:

TABLE VII Proposed Recommendation for PT. Telkom

\begin{tabular}{|c|c|c|}
\hline Recommendation & Define & MarketDemand \\
\hline Home Automation & $\begin{array}{l}\text { The ability to control theitems around the house, from the easiest } \\
\text { things until complicated things, just a simple push of a button or a } \\
\text { voice command. }\end{array}$ & $\begin{array}{l}\text { Basedonthesurveythere are } \\
\text { 66.7\% oftherespondentswantingtousethisproduct } \\
\text { (majorityPassionate business owner, Newbie startup, Digital } \\
\text { Socialite) }\end{array}$ \\
\hline Home Shopping & $\begin{array}{l}\text { Shopping carried out from one's own home by ordering goods } \\
\text { advertised on the internet, catalog, or on television channel. }\end{array}$ & $\begin{array}{l}\text { Basedonthesurveytoall persona there are } \\
\text { 44\%oftherespondentswhowantedtousethisproduct } \\
\text { (majorityAffectionate parents, Digital Socielite) }\end{array}$ \\
\hline Mobile remote TV & $\begin{array}{l}\text { Controlling television through just one remote but could beused for } \\
\text { more than one account (family members)to control their preferences } \\
\text { channel, marked the home shopping, etc. }\end{array}$ & $\begin{array}{l}\text { Basedonthesurveytoall persona there are } \\
\mathbf{4 4 \%} \text { oftherespondentswantingtousethisproduct (all persona) }\end{array}$ \\
\hline On the go services & $\begin{array}{l}\text { Smartphone users wanttobe able to control their device from the } \\
\text { distance (remotely), controlling their home phone from a distance, } \\
\text { their television channels. }\end{array}$ & $\begin{array}{l}\text { Basedonthesurveytoall persona there are } \\
\text { 72\% oftherespondentswhowantedtousethisproduct } \\
\text { (HobbyistAddict, Digital socialite,) }\end{array}$ \\
\hline
\end{tabular}

\section{References}

[1] BNG Design, (2016), Buyer Persona Guide, Quoted 11 October 2016 from http://www.bngdesign.net/wpcontent/uploads/2016/05/BNG-Design-Buyer-Personal.pdf

[2] Ireland R, Duane., Hoskisson, Robert E., \&Hitt, Michael A., (2013), The Management od Strategy Consepts and Cases, South Western: Cengage Learning.

[3] KementrianKomunikasidanInformatikaRepublik Indonesia, (2015), Indonesia RaksasaTeknologi Digital Asia, Quoted 6 October 2015 from https://www.kominfo.go.id/content/detail/6095/indonesia-raksasa-teknologidigital-asia/0/sorotan_media

[4] PT Telkom, (2015), Indihome Performance Tracking

[5] PT Telkom, (2015), IndiHome Web 2.0 : New Digital Channel to accelerate IndiHome Sales and Revenue. 
[6] Revella, Adele, (2011), The Buyer Persona Manifesto, Quoted 10 October 2016 from http://marketinglowcost.typepad.com/files/the_buyer_persona_manifesto.pdf

[7] Telkom Indonesia, (2015), Annual Report 2015: Building Indonesian Digital Society, Quoted 6 October 2016 from http://www.telkom.co.id/assets/uploads/2013/05/AR-TELKOM-2015_ENG.1.pdf 